\title{
Environmental DNA Surveys of Burmese Pythons in the Greater Everglades Ecosystem
}

Open-File Report 2021-1082 



\section{Environmental DNA Surveys of Burmese Pythons in the Greater Everglades Ecosystem}

By Caitlin E. Beaver, Gaia Meigs-Friend, and Margaret E. Hunter

Open-File Report 2021-1082 


\section{U.S. Geological Survey, Reston, Virginia: 2021}

For more information on the USGS - the Federal source for science about the Earth, its natural and living resources, natural hazards, and the environment—visit https://www.usgs.gov or call 1-888-ASK-USGS.

For an overview of USGS information products, including maps, imagery, and publications, visit https://store.usgs.gov/.

Any use of trade, firm, or product names is for descriptive purposes only and does not imply endorsement by the U.S. Government.

Although this information product, for the most part, is in the public domain, it also may contain copyrighted materials as noted in the text. Permission to reproduce copyrighted items must be secured from the copyright owner.

Suggested citation:

Beaver, C.E., Meigs-Friend, G., and Hunter, M.E., 2021, Environmental DNA surveys of Burmese pythons in the Greater Everglades Ecosystem: U.S. Geological Survey Open-File Report 2021-1082, 17 p., https://doi.org/10.3133/ ofr20211082.

Associated data for this publication:

Beaver, C.E., Meigs-Friend, G., and Hunter, M.E., 2021, Droplet digital PCR data for environmental DNA surveys of Burmese pythons in the Greater Everglades Ecosystem: U.S. Geological Survey data release, https://doi.org/10.5066/ PgHVM4VO.

Some data either are not available or have limited availability owing to sensitivity concerns. Contact the USGS Wetland and Aquatic Research Center for more information: https://www.usgs.gov/centers/wetland-and-aquaticresearch-center-warc.

ISSN 2331-1258 (online) 


\section{Acknowledgments}

This project was performed in collaboration with cooperating-party biologists who assisted with project formulation, sampling site designation, field work, and data interpretation. We would like to thank Stephanie Katircioglu (U.S. Geological Survey) for her assistance with field sample collection and laboratory sample processing. We would also like to thank Margaret Parrish (University of Florida) for her assistance in the laboratory as well. 



\section{Contents}

Acknowledgments ……...................................................................................................................

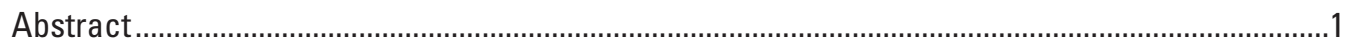

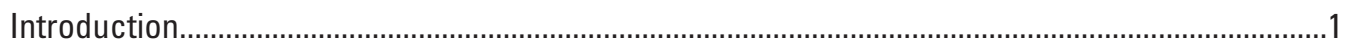

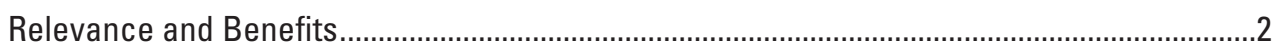

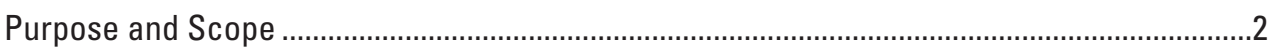

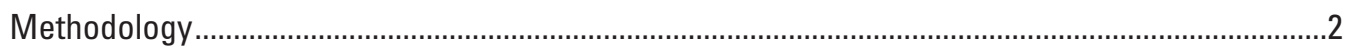

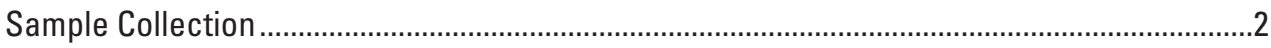

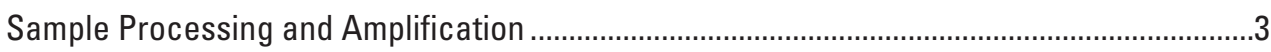

Concentration Analyses .........................................................................................................

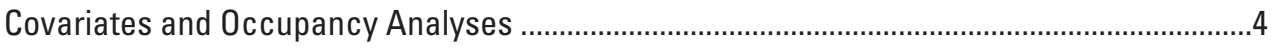

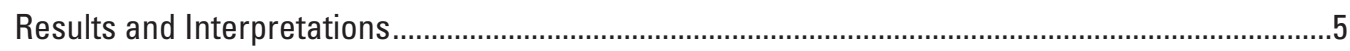

Summary Statistics and Positive Detections ............................................................................

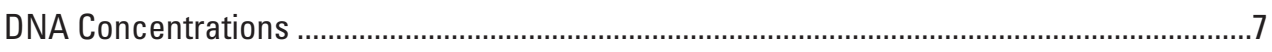

Covariates and Occupancy Modeling ...............................................................................

Interpretation of Models and eDNA Concentrations Relating to Inhibitors ............................9

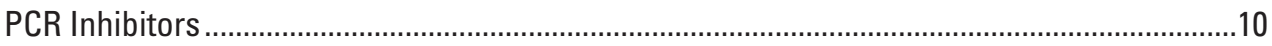

Recommendations for Future Studies .........................................................................

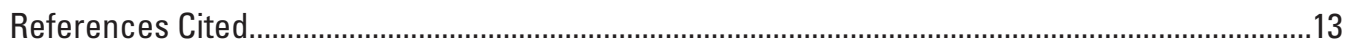

Appendix 1. Definitions and Explanations for Frequently Used Terminology................................17

\section{Figures}

1. Boxplots showing results from Bayesian occupancy modeling assessing covariates that influence python eDNA occurrence at a sampling site: canal or other waterbody; the presence or absence of structures; and python sightings or no sightings in the area of the sampling site...

2. Boxplots showing results from Bayesian occupancy modeling assessing covariates that influence conditional probability of occurrence of python eDNA in an individual sample given that a python is present at a site: salinity, water temperature, and presence or absence of floating vegetation.

3. Graphs showing results from Bayesian occupancy modeling assessing covariates that influence conditional probability of occurrence of python eDNA in a PCR replicate given that python eDNA is present in a sample: levels of inhibition; final number of Inhibitor Removal Kits.

\section{Tables}

1. Descriptions of covariate data collected in the field and laboratory and the land-use types grouped into overarching categories to assess patterns or predictors of python eDNA occurrence in eDNA occupancy models

2. Complete list of the sampling sites, minimum and maximum inhibition levels of samples from that site, and the minimum and maximum concentrations of target eDNA detected at each site

3. Bayesian estimates of model parameters for each model run independently ..................8

4. Bayesian occupancy model results reported for each site ..........................................12 


\section{Conversion Factors}

International System of Units to U.S. customary units

\begin{tabular}{lll}
\hline \multicolumn{1}{c}{ Multiply } & By & \multicolumn{1}{c}{ To obtain } \\
\hline millimeter (mm) & Length & \\
meter (m) & 0.03937 & inch (in.) \\
kilometer (km) & 3.281 & foot (ft) \\
kilometer (km) & 0.6214 & mile (mi) \\
meter (m) & 0.5400 & mile, nautical (nmi) \\
\hline & 1.094 & yard (yd) \\
\hline liter (L) & Volume & \\
liter (L) & 33.81402 & ounce, fluid (fl. oz) \\
liter (L) & 2.113 & pint (pt) \\
liter (L) & 1.057 & quart (qt) \\
liter (L) & 0.2642 & gallon (gal) \\
\hline
\end{tabular}

Temperature in degrees Celsius $\left({ }^{\circ} \mathrm{C}\right)$ may be converted to degrees Fahrenheit $\left({ }^{\circ} \mathrm{F}\right)$ as follows: ${ }^{\circ} \mathrm{F}=\left(1.8 \times{ }^{\circ} \mathrm{C}\right)+32$.

Temperature in degrees Fahrenheit $\left({ }^{\circ} \mathrm{F}\right)$ may be converted to degrees Celsius $\left({ }^{\circ} \mathrm{C}\right)$ as follows: ${ }^{\circ} \mathrm{C}=\left({ }^{\circ} \mathrm{F}-32\right) / 1.8$.

\section{Abbreviations}

$\begin{array}{ll}\text { Cl } & \text { confidence interval } \\ \text { ddPCR } & \text { droplet digital PCR } \\ \text { eDNA } & \text { environmental DNA } \\ \text { IPC } & \text { internal positive control } \\ \text { IRK } & \text { OneStep PCR Inhibitor Removal Kit } \\ \text { P/A } & \text { presence/absence } \\ \text { PCA } & \text { principal component analysis } \\ \text { PCR } & \text { polymerase chain reaction } \\ \text { qPCR } & \text { quantitative PCR } \\ \text { UV } & \text { ultraviolet }\end{array}$




\title{
Environmental DNA Surveys of Burmese Pythons in the Greater Everglades Ecosystem
}

\author{
By Caitlin E. Beaver, Gaia Meigs-Friend, and Margaret E. Hunter
}

\begin{abstract}
Improving the probability of detecting invasive giant snakes is vital for the management of emerging or established populations. Burmese pythons occupy thousands of square kilometers of mostly inaccessible habitats in Florida. Environmental DNA (eDNA) methods have been shown to be time and cost effective in a number of systems and may be preferable to traditional detection methods for constrictor snakes, having been shown to be effective at detecting Burmese pythons where traditional and novel detection methods have failed. The purposes of this study were (1) to estimate Burmese python eDNA occurrence in the Greater Everglades Ecosystem based on land-use type; and (2) to conduct preliminary surveys within the Greater Everglades Ecosystem for positive eDNA detections. Twenty-eight sites were sampled in the Greater Everglades Ecosystem, with 5 field replicate samples per site, for a total of 140 water samples collected. Python eDNA was detected in samples from 25 of the 28 sites by using droplet digital polymerase chain reaction amplification. Abiotic parameters were collected and explored, but we found no conclusive relationship among them and python eDNA detections. eDNA monitoring of aquatic habitats can assist in identifying newly colonized areas where pythons have not been previously detected, as well as movement corridors and pathways of dispersal. This information could be used to delimit a population boundary as it expands further to the north in peninsular Florida.
\end{abstract}

\section{Introduction}

Improving the probability of detecting invasive giant snakes is vital for the management of emerging or established populations. Detecting invasive species at low densities or prior to establishment is critical for successful control and eradication (Lodge and others, 2006; Kolar and others, 2010; Darling and Mahon, 2011). Burmese pythons occupy thousands of square kilometers of mostly inaccessible habitats in Florida. Tools for detection and control (for example, detector dogs, remote sensing, attractant traps, "Judas snakes," etc.) have provided low detection of Burmese pythons in Florida with varying degrees of success (C.M. Romagosa, Auburn University, written commun., 2011; Reed and others, 2011; Smith and others, 2016). Estimation of detection probabilities have been inadequately low using traditional tools such as visual searching or trapping (less than 0.05 percent) (Reed and others, 2011). Detection of these large constrictor snakes is crucial because they are detrimental to native species, especially imperiled or at-risk species, such as wading birds (Greene and others, 2007; Snow and others, 2007; Dove and others, 2011; Orzechowski and others, 2019).

Environmental DNA (eDNA) methods can assist with early detection of novel invasive species and range delimitation or expansion for established species. eDNA originates from cellular material shed by organisms (via skin, excrement, etc.) into water and can be used for species identification (Dejean and others, 2011; Thomsen and others, 2012b). eDNA methods have been shown to be time and cost effective in a number of systems (Goldberg and others, 2011; Jerde and others, 2011; Takahara and others, 2012; Thomsen and others, 2012b; Mahon and others, 2013) and may be preferable to traditional detection methods for constrictor snakes, having been shown to be effective at detecting Burmese pythons where traditional and novel detection methods have failed (Hunter and others, 2015).

Quantitative polymerase chain reactions (qPCR) eDNA methods for detection of Burmese pythons have been developed for real-time PCR and droplet digital PCR (ddPCR) platforms and have been assessed with water samples from Everglades National Park and throughout southern Florida (Hunter and others, 2015, 2019b). Of note, detections have occurred at two locations near the northern-central limit of their known range and more recently, water samples contained python eDNA in Arthur R. Marshall Loxahatchee National Wildlife Refuge, north of the previously defined northern range limit (Hunter and others, 2019b). These detections indicate the plausibility of Burmese pythons expanding their range northward.

For accurate range delimitation, eDNA sampling design needs to incorporate optimal sample numbers, densities, and locations. Without proper statistical power, false-negative eDNA detections, where eDNA is not detected but pythons are present, can occur. Sampling design also needs to account for the species densities and the effects of different types of habitats and land-use patterns on those densities (Furlan and 
others, 2016). For example, collecting more water sample replicates can account for low densities, as can sampling favorable habitat types, and monitoring possible corridors for expansion.

As compared to other aquatic species (for example, fish and amphibians), detection of eDNA from semi-aquatic reptiles is challenging due to the limited amounts of eDNA shed directly into waterbodies. Furthermore, the low densities of pythons can often result in low eDNA concentrations. An added challenge includes the removal of environmental inhibitors typically found in water samples from South Florida. For these reasons, detection of pythons in areas that were not previously surveyed may not produce highly conclusive results. Therefore, adaptive sampling design and analysis based on calculated occurrence and detection estimates can improve confidence in nondetections or the absence of eDNA for management and control actions.

\section{Relevance and Benefits}

eDNA has the potential to be a powerful tool for enhancing early detection of giant constrictor snakes for rapid response as well as providing a decision-support tool for long-term management strategies. Noninvasive monitoring of aquatic habitats can assist in identifying newly colonized areas where pythons have not been previously detected, as well as movement corridors and pathways of dispersal. This information could be used to delimit a population boundary as it expands further to the north in peninsular Florida. More precise information on the presence of harmful constrictors in critical habitats can inform spatiotemporal assessment of at-risk to imperiled native species, such as ground-dwelling birds and the Florida panther, and potentially allow for targeted removal efforts prior to major ecological and economic impacts. eDNA tools can also assist with short- or long-term monitoring to determine whether control or eradication efforts have been successful.

\section{Purpose and Scope}

The purposes of this study were (1) to estimate Burmese python eDNA occurrence in the Greater Everglades Ecosystem based on land-use type; and (2) to conduct preliminary surveys within the Greater Everglades Ecosystem for positive eDNA detections. The results of these efforts can help with early detection and decision support regarding Burmese pythons within the Greater Everglades Ecosystem. Based on the mechanics of eDNA in the water, the detection of python eDNA does not allow for direct conclusions to be made about the number or proximity of snakes in the study area; however, the information could be used to aid future management decisions.

\section{Methodology}

See Appendix 1 for definitions and explanations of frequently used terminology.

\section{Sample Collection}

eDNA samples were collected from the Greater Everglades Ecosystem during May 20-22, 2019. Sampling sites were chosen by cooperating-party biologists in consultation with USGS scientists. Twenty-eight sites were sampled, with 5 field replicate samples per site, for a total of 140 water samples collected. Sampling sites were chosen in a transect pattern of interconnected canals with sites upstream and downstream of one another in an effort to identify potential corridors for python movement and land-use patterns within the transects or spanning the transects. Sample collection methodology was adapted to the type of waterbody being sampled. Canals were sampled from one bank with each replicate sampled in increments of about 8.3 meters $(\mathrm{m})$ upstream of the previous replicate. Small ponds, less than $9 \mathrm{~m}$ in diameter, were sampled at each corner and then at a center location with each replicate $8.3 \mathrm{~m}$ or less apart, depending on the size of the waterbody. Larger ponds or lakes were sampled in a "U" pattern. Water samples of 950 milliliters $(\mathrm{mL})$ were collected for each field replicate sample in 1-liter (L) DNase- and RNasefree bottles (Nalgene), and eDNA was preserved with a solution of $1 \mathrm{~mL}$ of sodium acetate $(3 \mathrm{M})$ and $33 \mathrm{~mL}$ of 95 percent ethanol (Díaz-Ferguson, 2014; Moyer and others, 2014).

Field control samples $(\mathrm{N}=6)$ were prepared for the sampling trip in the USGS Wetland and Aquatic Research Center laboratory in Gainesville, Florida, by adding $950 \mathrm{~mL}$ of ultrapure water to a sterilized water bottle. At mid-day and end-of-day sites on each sampling day, the ultrapure water was poured into a second sterilized bottle, and preservation solution was added. On May 22, 2019, field negatives were completed at the end of sampling. Water samples were stored on ice during sampling and transferred to freezers upon arrival at the cooperating offices at the end of each day.

Abiotic environmental data were collected from each site, either after the water samples were collected or downstream of water collection points as close to the sites as possible without interfering with the samples. Salinity and water temperature were measured with a model 30 YSI meter (YSI Inc., Yellow Springs, Ohio) (table 1). Photographs were taken of each site to determine vegetation presence. Other notes on waterbody type (canals, ponds, lakes, etc.) were recorded along with presence of nearby structures (for example, pumps, culverts, and [or] pipes; table 1). An anecdotal factor of previous python sightings in the area was also noted for each site (table 1). 
Table 1. Descriptions of covariate data collected in the field and laboratory and the land-use types grouped into overarching categories to assess patterns or predictors of python eDNA occurrence in eDNA occupancy models.

[eDNA, environmental DNA; ppt, parts per thousand; ${ }^{\circ} \mathrm{C}$, degrees Celsius; ddPCR, droplet digital polymerase chain reaction; The attribute represents the assignment of variables at each site. Inhibitor Removal Kits (IRKs) were used to remove polymerase chain reaction (PCR) inhibitors from isolated eDNA as needed]

\begin{tabular}{|c|c|c|}
\hline Covariate & Attribute & Description \\
\hline Canals & Presence or Absence & Waterbody type was either canal (1) or other ( 0 , for example, pond, reservoir, lake). \\
\hline Structures & Presence or Absence & $\begin{array}{l}\text { Manufactured structures (for example, culverts, pumping systems, boat ramps) were } \\
\text { present in the direct vicinity of the site (1) or not }(0) \text {. }\end{array}$ \\
\hline Pythons & Presence or Absence & Previous visual detection of python in the direct vicinity of the site (1) or not (0). \\
\hline Salinity (ppt) & Continuous & Salinity (ppt) was collected at each site in the field. \\
\hline Inhibition level & Discrete $(1-5)$ & $\begin{array}{l}\text { ddPCR inhibition levels characterized into categories of no inhibition (1), slightly in- } \\
\text { hibited (2), partially inhibited (3), mostly inhibited (4), and completely inhibited (5). }\end{array}$ \\
\hline Final number of IRKs & Discrete $(1-8)$ & The effort made to reduce inhibition based on the number of IRKs run on each sample. \\
\hline \multicolumn{3}{|r|}{ Land-use categories } \\
\hline Upland & & $\begin{array}{l}\text { Non-Forested and Forested. Includes Pine Flatwoods, Temperate Hardwoods, } \\
\text { Hardwood Conifer Mix, Oak with Saw Palmetto, Brazilian Pepper, Melaleuca, } \\
\text { Herbaceous, Herbaceous-Dry Prairie, and Mixed Rangeland land-use types. }\end{array}$ \\
\hline Wetlands, exotic & & $\begin{array}{l}\text { Includes Wet prairie-disturbed, Hydric Brazilian Pepper, and Hydric Melaleuca land- } \\
\text { use types. }\end{array}$ \\
\hline Wetlands, native & & $\begin{array}{l}\text { Includes Mixed Wetland Hardwoods, Wetland Forested Mix, Wetland Hardwood } \\
\text { Forested Mix, Wet Prairie, Cypress, Hydric Pine, Freshwater Marsh, Wetland } \\
\text { Shrubs, Willow, Hydric Cabbage Palm, and Cypress with Graminoid Understory } \\
\text { land-use types. }\end{array}$ \\
\hline Open water & & Includes Reservoir and Pond land-use types. \\
\hline
\end{tabular}

\section{Sample Processing and Amplification}

Frozen water bottles from the field were transported to the USGS Wetland and Aquatic Research Center laboratory and stored in freezers at -20 degrees Celsius $\left({ }^{\circ} \mathrm{C}\right)$ to be filtered as soon as possible. Standard-duty dry piston pumps, model 2522B-01, from Welch (Mt. Prospect, Illinois), were used at approximately 26 inches $\mathrm{Hg}$ vacuum. Water samples were filtered following Renshaw and others (2015), using polyethersulfone filters $(1.2$-micrometer $[\mu \mathrm{m}]$ pore size, 47 -millimeter $[\mathrm{mm}]$ filter diameter) from Sterlitech (Kent, Washington). Funnels were rinsed with $1 \mathrm{X}$ phosphate-buffered saline $\mathrm{pH}$ 7.4) to flush eDNA bound to the sides of the plastic. Filters were placed in a 2,000-microliter $(\mu \mathrm{L})$ modified CTAB buffer (Hunter and others, 2019a) and stored at $4{ }^{\circ} \mathrm{C}$ until DNA isolation was complete (about 1 week).
eDNA was isolated from the polyethersulfone filters by using the phenol chloroform method outlined in Experiment 2 of Hunter and others (2019a). Extracted eDNA was suspended in $100 \mu \mathrm{L}$ of $1 \mathrm{X}$ low-EDTA TE buffer and quantified by using an Epoch Microplate Spectrophotometer (BioTek Instruments, Inc., Winooski, Vermont). Laboratory negative control samples were used to test for contamination in the filtering and isolation processes by using ultrapure water or buffer in place of the sample. The OneStep PCR Inhibitor Removal Kit (IRK; Zymo Research, Irvine, California) was used to remove PCR inhibitors from isolated eDNA as needed (using one to eight columns) dependent on the brown color of the eDNA sample, caused by inhibitors such as humic acid or tannins, and dependent on ddPCR inhibition levels. The IRK process involves isolated eDNA filtered through a column matrix designed to bind some common PCR inhibitors, such as humic acid, while eDNA fragments are washed through the column matrix. 
ddPCR amplification was performed with the QX200 Droplet Digital PCR System (Bio-Rad, Hercules, Calif.) for precise quantification with detection down to a single molecule. Briefly, the PCR is partitioned into 10,000-20,000 nanofluidic droplets that each have a random distribution of zero, one, or several molecules of the target eDNA per droplet. Each droplet is scanned to detect whether the target strand of eDNA is present or absent. Quantification may be more accurate than qPCR when PCR inhibitors are present due to inhibitor partitioning and binary quantification (Whale and others, 2012; Hayden and others, 2013; Huggett and others, 2013; Doi and others, 2015). The species-specific Burmese python TaqMan qPCR assay developed by Hunter and others (2015) was successfully transferred to the QX200 Droplet Digital PCR platform using protocols described in Hunter and others (2017). Briefly, ddPCR amplification was performed in a total reaction volume of $25 \mu \mathrm{L}$, containing $4.0 \mu \mathrm{L}$ of eDNA, $12.5 \mu \mathrm{L}$ of ddPCR mix (Bio-Rad, Hercules, Calif.), a final concentration of 150 nanomolar (nM) probe (VIC), and $800 \mathrm{nM}$ of each primer. To distinguish between true target negatives and PCR inhibition, an internal positive control (IPC) PrimePCR Probe Assay containing 1.0 $\mu \mathrm{L}$ of Probe FAM PCR mix and $0.20 \mu \mathrm{L}$ of PrimePCR Template for Probe Assay (diluted 1:100 from stock; YWHAZ Rhesus Monkey; Bio-Rad) was included. Droplet generation was performed by using a BioRad Automated Droplet Generator (Bio-Rad, Hercules, Calif.). PCR replicates $(\mathrm{N}=5)$ were performed for each of the water samples. Genomic DNA extracted from Burmese python tissue was used as a positive control $(\mathrm{N}=2)$ and was included on each experimental ddPCR plate, in addition to no-template controls $(\mathrm{N}=3$ or 4$)$. Detection thresholds were manually set by using QuantaSoft Version 1.7.4.0917 software (Bio-Rad, Hercules, Calif.) in accordance with Bio-Rad recommendations. The detection threshold is marked in accordance with manufacturers' recommendations, about two-thirds between the bottom of the positive and the top of the negative droplets but varies slightly for each ddPCR plate depending on inhibition levels and droplet formulation and (or) shearing.

Many samples in this study contained high levels of environmental PCR inhibitors, such as tannins and humic acid, originating from plants and soils. These PCR inhibitors can prevent or reduce nucleic acid amplification during PCR and artificially lower measurements of true eDNA concentrations, percentages of positive samples, and occupancy and detection estimates. An IPC added to a PCR can be used to indicate how well each PCR is able to amplify target eDNA and to monitor for the presence of inhibitors that could reduce the efficiency of the amplification. IPCs are simultaneously amplified in the same reaction well with the sample. If the amplification of the IPC in the reaction with the sample is reduced below expected levels, this demonstrates the likely presence of inhibitors in the sample. The amount that the IPC amplification is reduced below expected levels indicates the relative amount of PCR inhibition present in the sample.

\section{Concentration Analyses}

All ddPCR data were scored by using QuantaSoft software (Bio-Rad), and inhibition levels and presence of positive python droplets were determined for each sample. Samples that were inhibited and absent of any positive droplets were omitted from the concentration analyses. Concentrations were calculated by using an optimized method for ddPCR (Dorazio and Hunter, 2015; R Core Team, 2019), based on a comparison of the number of positive python droplets with the total number of droplets in a plate well. Concentrations of positive droplets were converted into copies/L template units for comparison to other studies. For simplicity, the metric of copies/L template is used for all calculations throughout this report and from here on will be referred to as "copies." Minimum, maximum, and average copies were calculated and reported for any samples with positive detection, excluding any zeros.

Semi-aquatic snakes tend to primarily shed low levels of eDNA because of their skin shedding patterns, intermittent fasting, and use of water. As a result of this, minimal copies of eDNA are normally collected in a water sample, which is stochastically subsampled for the PCR. To categorize a positive detection, the "liberal" and "conservative" criteria of Mosher and others (2018) were followed to provide true transparency of data while also adhering to the conservative nature of the scientific community in standardizing field-wide thresholds. Under the liberal categorization, samples were considered to have a positive occurrence of python eDNA if a single ddPCR replicate amplified one or more positive droplets. The liberal approach acknowledges that a molecule of target eDNA was amplified and present in the sample, but the results were not reproduced in one of the other four PCR replicates; however, more PCR replicates of the sample could result in an additional detection. Under the conservative categorization, samples were considered to have a positive occurrence of python eDNA if multiple ddPCR replicates amplified one or more positive droplets. As a more conservative approach, this criterion requires a positive droplet to be detected in multiple PCR replicates, further supporting the presence of target eDNA. By following the previously described criteria, a site could be considered a positive or inconclusive detection based on the positive eDNA in one or more PCR replicates from one or more samples.

\section{Covariates and Occupancy Analyses}

Covariates were collected in the field and the laboratory and compiled with land-use types observed at each site to further assess patterns or predictors of python eDNA occurrence (table 1). Salinity and temperature data were collected in the field and used to delineate differences among sampling sites. For example, waterbody type was converted into a binomial variable of canal (1) or not ( 0 , for example, pond, reservoir, lake); only 4 of 28 sites sampled were not canals, thus resulting in skewed sample sizes. Likewise, the presence of floating 
vegetation, the presence of manufactured structures, such as culverts, pumping systems, and boat ramps, and previous visual detections of pythons in the area were converted into binomial variables to simplify data (table 1). In the laboratory, ddPCR inhibition levels were initially characterized into categories of "no inhibition," "slightly inhibited," "partially inhibited," "mostly inhibited," and "completely inhibited." These categories were then transformed into discrete variables of values $1-5$, ranging from no inhibition to completely inhibited. The final number of IRKs was also used as a laboratory covariate because it represents the effort made to reduce inhibition and can be compared to the presence of eDNA after said effort. After sample collection, land-use types, based on the Florida Land Use Classification and Cover System (2010; data provided by the cooperating party), were identified in a 400-m radius from the sampling site by using ArcMap (Esri, 2018). A 400-m radius was determined because the two sites closest to each other were about 1 kilometer apart, leaving a 400-m radius to be specific to the site, without overlap. A total of 36 land-use types were identified for the 28 sampling sites and were condensed into the following 7 overarching categories: Urban, Agricultural, Upland, Wetlands (exotic), Wetlands (native), Open water, and Disturbed as determined by the cooperating-party biologists (table 1 ).

Principal component analyses (PCA) were used to explore patterns in abiotic, land-use, and laboratory parameters correlating to detection or nondetection at sampling sites and high or low levels of inhibitors. PCA creates synthetic variables (components) to explain the variation seen among the targeted variables and the covariates that may influence them. We statistically assessed the relations of environmental and laboratory covariates and the detection or nondetection of eDNA. All covariates were centered and scaled, where applicable, to transform the data and create uniformity between discrete and continuous variables (BiplotGUI, La Grange and others, 2009; R Core Team, 2019).

Occupancy models were used to evaluate sampling site and PCR replicates to quantify the probabilities of detecting python eDNA given the covariates collected. The package in R software with the occModel() function was used to quantify the uncertainty and imperfect detection of eDNA methodology with statistical modeling (Dorazio and Erickson, 2018). The details of the Bayesian occupancy model are described in Hunter and others (2015) and in Dorazio and Erickson (2018). Briefly, the model calculates median estimations for the (1) probability of occurrence of eDNA at a sampling site $(\psi),(2)$ the conditional probability of eDNA found in a single sample of a site given that python eDNA is present $(\theta)$, and (3) the conditional probability of detection of eDNA in a PCR replicate given that eDNA is present in the sample $(\rho)$. The three levels allow us to model potential variables that may influence the variation and imperfect detection at each level of the eDNA process. Covariates that may influence the probability of python eDNA occurrence at a given site were modeled as $\alpha$ and included canals (Presence/Absence [P/A]), structures (P/A), and previous python sightings (P/A). Covariates that may influence the probability of python eDNA occurring in a sample (water bottle) were modeled as $\beta$ and included salinity (ppt), temperature $\left({ }^{\circ} \mathrm{C}\right)$, and floating vegetation (P/A). Finally, covariates that may influence the detection of eDNA in a PCR replicate were modeled as $\delta$ and included inhibition level and the final number of IRKs. The site variables were centered and scaled, but the original laboratory variables were used because the centered and scaled laboratory variables returned values that were not acceptable in the model. Based on previous studies, parameters were identified as having a weak relationship to probability of occurrence $(-0.5<\alpha / \beta / \delta<0.5)$ or having no relationship $(-0.1<\alpha / \beta / \delta<0.1)$ (Dorazio and Erickson, 2018; Hunter and others, 2019b).

Two models were run to identify field and laboratory variables that may have affected individual samples as opposed to whole sampling sites: (1) sites with covariates, samples with covariates, and PCR replicates constant and (2) PCR replicate conditions with covariates and all other factors constant. Initial Bayesian models were run with 11,000 iterations and a burn-in period of 1,000 followed by an additional 5,000 iterations and another burn-in period of 1,000. Each model was assessed for stability by evaluating the convergence of the Markov chain estimates and autocorrelation plots. Furthermore, the medians for each model parameter were reported with 95-percent confidence intervals (CI) for context. Variables were determined statistically significant in affecting eDNA occurrence if the 95-percent CI did not include zero. Variables presented in a presence/absence format were evaluated in boxplots. If the interquartile range of each boxplot did not overlap, then it was considered to be a difference in the occurrence estimates. If the median line of one boxplot lies outside of the interquartile range of the other boxplot, there is likely to be a difference in occurrence estimates.

\section{Results and Interpretations}

\section{Summary Statistics and Positive Detections}

We sampled 28 sites within the Greater Everglades Ecosystem (S001-S028; table 2). In total, 24 sites were in canals interconnected through South Florida, and the other 4 sites were in ponds, lakes, or reservoirs (S001-S003, S009; table 2). Floating vegetation and manufactured construction in the form of culverts, pump systems, or boat ramps were noted near 10 of the sampled sites.

Python eDNA was detected at 25 of the 28 sampling sites under the liberal criterion, which identified a molecule of target eDNA present in one droplet in one sample, but the results were not reproduced in one or more of the replicate PCRs or samples. Only three sites (S002, S004, and S009) did not have python eDNA detections (table 2). Inhibition levels for site S002 ranged from partially to completely inhibited, with one out of five samples able to be analyzed. Inhibition levels for site S004 ranged from none to mostly, with all five samples 
Table 2. Complete list of the sampling sites, minimum and maximum inhibition levels of samples from that site, and the minimum and maximum concentrations of target eDNA detected at each site.

[eDNA, environmental DNA; copies, concentrations of positive droplets; /L template, refers to the volume of water that was collected and processed for potential eDNA molecules (for example, 1 liter of water collected); Total samples analyzed excludes samples that had inhibition and no evidence of positive detection. Sampling sites considered positive detections with replicated results are in bold type, with sites having non-replicated positive detections in italic type]

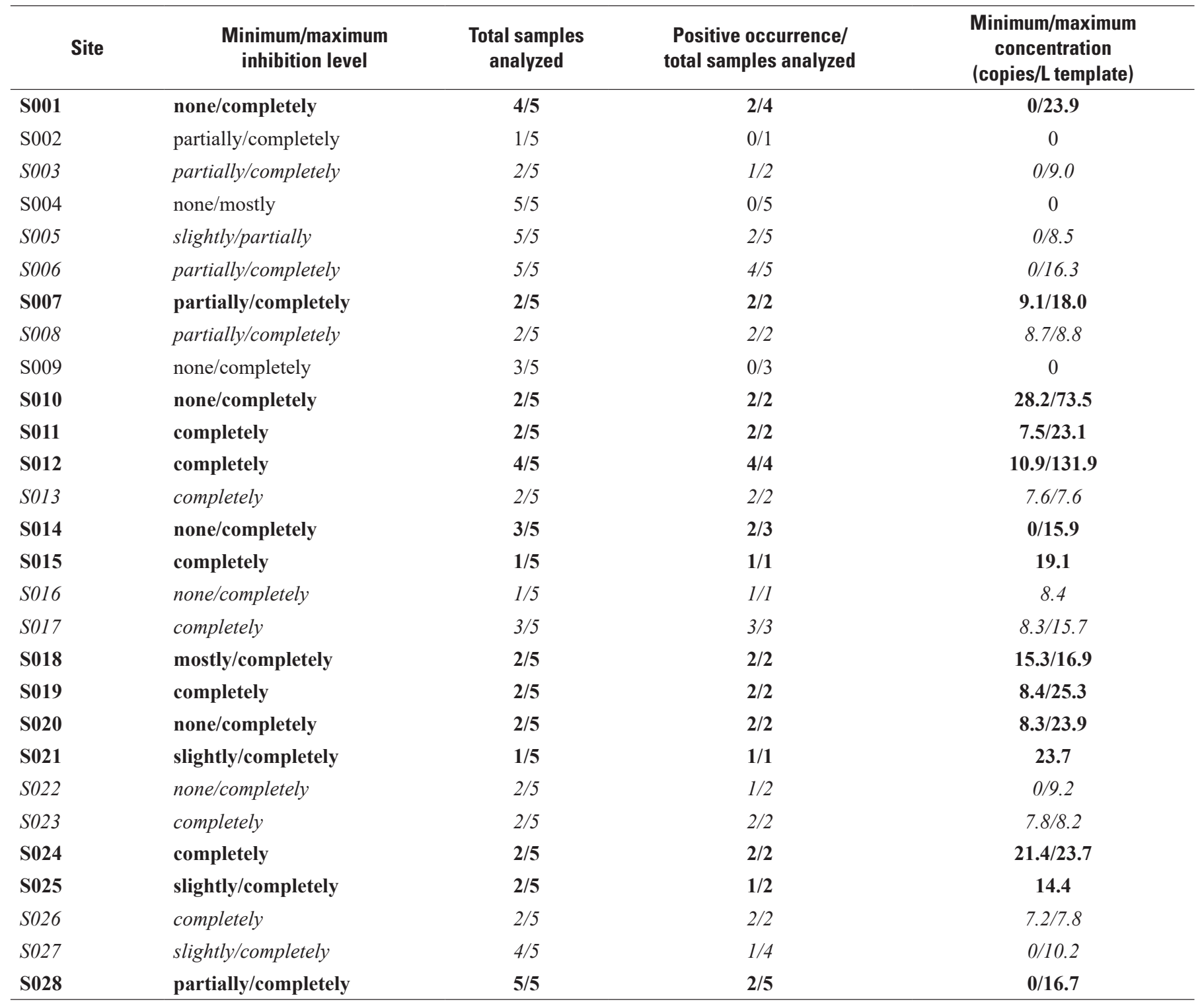

analyzed, and inhibition levels for site S009 ranged from none to completely, with three out of five samples analyzed. Site S004 had no detection in all five samples, allowing for confidence of no detection of eDNA at this site with our sampling protocol. The variation in inhibition makes it difficult to assign confidence in the other two nondetection sites, but we cannot rule out the chance that these may have yielded a positive PCR replicate with lower levels of inhibition. Protocol testing and development started when the high levels of inhibition were identified and are ongoing to reduce the level of inhibition in eDNA samples of this type.
All sampling sites had at least one sample that was able to be assessed for concentration because they indicated either no inhibition or inhibition with evidence of possible positive detection. Of the 140 total samples, 73 (52.1 percent) of the samples had no evidence of inhibition or inhibition with positive detection. Under the liberal criterion, of those 73 samples, 50 samples were considered positive for python eDNA, with 1 or more ddPCR droplet indicating concentrations greater than zero. Of those 50 samples, under the liberal criterion, there were 23 positive sites within the Greater Everglades Ecosystem. Under the conservative criterion, which required positive droplets in multiple PCR replicates, 14 sites within 
the Greater Everglades Ecosystem had positive python eDNA detection (table 2). Data from this study are available in Beaver and others (2021).

\section{DNA Concentrations}

The concentration of eDNA is presented in units of copies/L template (hereafter "copies") because $1 \mathrm{~L}$ of water was collected in each sample. eDNA concentrations were similar between samples collected at S001-S023 ( $\mathrm{n}=40$ samples, $\min =7.1$ copies, $\max =131.9$ copies, average $=18.0$ copies ) and S024-S028 $(\mathrm{n}=10$ samples, $\min =7.2$ copies, $\max =23.7$ copies, average $=13.1$ copies) when excluding zeros. Of the samples included in the concentration analyses and sampling sites with positive detection, two samples had positive droplets above 30 copies, and both had complete levels of inhibition (S010D [73.5 copies] and S012A [131.9 copies]). Site S012 had high concentrations of positive droplets in four out of five samples (10.9-131.9 copies), along with complete levels of inhibition. The high concentration of eDNA present, combined with the complete inhibition level in all four samples analyzed, indicates the sampling of a clump of python biological matter or strongly indicates that a python was in the area.

The average numbers of copies, including zeros, for S001-S023 (average $=12.4$ ) and S024-S028 (average $=$ 8.71) are lower than the average numbers of copies from the Arthur R. Marshall Loxahatchee National Wildlife Refuge study (Hunter and others, 2019b). The Arthur R. Marshall Loxahatchee National Wildlife Refuge sampling events averaged from 40 copies in 2016 to 111 copies in 2015, with ranges of individual samples as high as 1,398 copies (Hunter and others, 2019b). The Stormwater Treatment Areas 3 \& 4 (connected to the eastern boundary of Holey Land Wildlife Management Area) and Water Conservation Area 2 (connected to the southwest boundary of Arthur R. Marshall Loxahatchee National Wildlife Refuge), all near the Greater Everglades Ecosystem and southeast of Lake Okeechobee, were sampled in the Arthur R. Marshall Loxahatchee National Wildlife Refuge study, with an average of 63 copies in 2014. Water Conservation Area 3 had an average of 30 copies in 2016, including zeros (Hunter and others, 2019b).

Another important study on Burmese python occurrence in the Greater Everglades Ecosystem is Hunter and others (2015), but it is difficult to compare those results to the results from the present study because they used qPCR amplification techniques as opposed to the ddPCR technique used here. Using three PCR replicates, python eDNA was detected in about 33 percent of samples in concentrations ranging from 4.90 to 5.63 molecules per $\mu \mathrm{L}$ (Hunter and others, 2015). Also nearby the current study in the Greater Everglades Ecosystem, Hunter and others (2015) detected python eDNA in Storm Water Treatment Area 5, connected to the western boundary of Rotenberger Wildlife Management Area, (in about 16 percent of samples collected) in lower concentrations between 1.45 and 2.21 molecules $/ \mu \mathrm{L}$ in two or three PCR replicates.
When the results from the current study are scaled down to copies/ $\mu \mathrm{L}$ for comparison to the 2015 study, all samples have concentrations less than 0.75 copies $/ \mu \mathrm{L}$ except for sample S012A which has 1.3 copies $/ \mu \mathrm{L}$. A total of 35.71 percent of samples analyzed in this study had a positive detection. As a very general comparison, the percentage of samples with positive detections for the five sampling events in the Arthur R. Marshall Loxahatchee National Wildlife Refuge study ranged from 21 to 48 percent (Hunter and others, 2019b), placing the results of the current study in the middle of that range. The many environmental, spatial, and temporal differences and the various details in the sampling analyses, however, make direct comparisons between these studies difficult.

\section{Covariates and Occupancy Modeling}

PCA and the occupancy modeling did not reveal a reliable pattern among positive detections and the assessed abiotic factors or land-use types for sampling sites. The PCA did not detect any relationships of abiotic factors with the level of inhibitors found within samples or with the level of python eDNA occurrence among sites. Furthermore, the PCA did not show a pattern between land-use type and positive or inconclusive detections. Conclusions about the site densities for various land uses are unreliable because point densities are relative to the data being evaluated. In general, positive detections of python eDNA were observed in a higher density of the exotic wetlands land-use type where inconclusive detections were observed at a higher density in the open water land-use type than other land uses. A higher density of sites, in this case, may indicate a cluster of no more than four sites, which is a small sample size and difficult to interpret.

The Bayesian occupancy model evaluated a general relationship between abiotic parameters and the general consensus comparisons of python eDNA occurrence in all samples and all sites. The presence of pythons previously identified in the area and the presence of human-made structures were positively correlated with python eDNA occurrence, but the correlations were not statistically significant. Presence of canal waterbodies was the only abiotic parameter with a statistically significant positive relationship (95-percent CI $=0.32-2.12$ ) to the probability of python eDNA occurrence (table 3 ). This result is likely because 24 of the 28 sites sampled were canals, and 25 of the 28 sites had positive eDNA detection, leading to a high probability of correlation because 3 out of the 4 noncanal waterbodies had no detections of python eDNA. The presence of floating vegetation and salinity appeared to have a weak negative relationship with the probability of python eDNA occurrence, whereas temperature seemed to have no relationship (table 3). In the second model, which evaluated the laboratory parameters across all samples, the probability of python eDNA occurrence in PCR replicates had a weak negative relationship with final number of IRKs run on a sample and a positive relationship with the numerical inhibition level. 
Table 3. Bayesian estimates of model parameters for each model run independently.

[Covariates for site $(\beta)$, sample $(\alpha)$, and PCR replicate $(\delta)$ are reported as mean and median values. The analysis returns only an intercept value when the parameter is kept constant. The 2.5 (lower) and 97.5 (upper) percentiles are reported to reflect the posterior summary of Markov chain Monte Carlo (MCMC) iterations. Mean and median values reflecting the relationship each covariate has to probability of occurrence at each respective scale are also reported]

\begin{tabular}{|c|c|c|c|c|c|}
\hline & Model parameters & Mean & Median & Lower & Upper \\
\hline \multirow[t]{9}{*}{ Model 1} & $\beta$.Intercept & 0.53 & 0.28 & -0.44 & 1.18 \\
\hline & $\beta$. StructuresPA & 0.54 & 0.68 & -0.16 & 2.27 \\
\hline & $\beta . P y t h o n s P A$ & 0.28 & 0.54 & -0.26 & 0.67 \\
\hline & B.CanalPA & 1.37 & 1.82 & 0.32 & 2.12 \\
\hline & $\alpha$. Intercept & 0.23 & 0.18 & -0.26 & 1.09 \\
\hline & a.FloatingVegetationPA & -0.04 & -0.07 & -0.77 & 0.83 \\
\hline & $\alpha$. Salinity & -0.22 & -0.16 & -1.13 & 0.22 \\
\hline & $\alpha$. TempC & 0.10 & 0.09 & -0.31 & 0.57 \\
\hline & $\delta$.Intercept & -0.77 & -0.77 & -1.05 & -0.52 \\
\hline \multirow[t]{5}{*}{ Model 2} & $\beta$. Intercept & 1.6 & 1.6 & 0.8 & 2.8 \\
\hline & $\alpha$. Intercept & 0.2 & 0.2 & -0.2 & 0.7 \\
\hline & $\delta$. Intercept & -0.9 & -0.9 & -1.5 & -0.3 \\
\hline & $\delta$.FinalIRK & 0.1 & 0.1 & 0.0 & 0.2 \\
\hline & 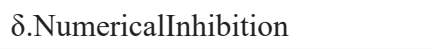 & -0.1 & -0.1 & -0.3 & 0.0 \\
\hline
\end{tabular}

After the consensus comparisons, occupancy models individually analyzed the relationships among covariates and individual sites, samples, and PCR replicates (figs. 1-2). A higher probability of python eDNA occurrence was found at canal sites than at other waterbodies (fig. $1 A$ ). The presence or absence of manmade structures made very little difference in python eDNA occurrence (fig. $1 B$ ). Likewise, if a python had been previously found in an area, there was very little change in the probability of python eDNA occurrence (fig. 1C). Results varied for covariates that were modeled as affecting both site and sample occupancy. As salinity increased from 0.10 to $0.40 \mathrm{ppt}$, the median conditional probability of detecting python eDNA decreased, although the CI were very wide (fig. $2 A$ ). Samples from a wider array of salinities may need to be collected to determine a pattern in python eDNA occurrence because 0.10 to $0.40 \mathrm{ppt}$ are very minute amounts in freshwater and may not be interpretable in this study. Salt is used to preserve eDNA, and warmer temperatures could mean pythons are moving more, but high salinity and temperatures in the environment can degrade eDNA quickly (Thomsen and others, 2012a; Goldberg and others, 2016; Sassoubre and others, 2016; Collins and others, 2018). Median conditional probability of detecting python eDNA increases from 0.4 to 0.65 as temperatures rise from 22 to $32{ }^{\circ} \mathrm{C}$ (fig. $2 B$ ). The presence of vegetation could potentially shelter eDNA from ultraviolet (UV) radiation or prevent transport downstream; however, floating vegetation did not seem to influence the median conditional probability of detecting python eDNA in a water sample (fig. $2 \mathrm{C}$ ).
Comparisons with laboratory covariates showed varying results. Level of inhibition did not seem to indicate a pattern related to the median conditional probability of detecting python eDNA in a PCR replicate, although samples that were completely inhibited showed the most variation in median probabilities (fig. $3 A$ ). Final number of IRKs indicated a pattern almost as a normal distribution where peak probability of detecting python eDNA in a PCR replicate was about three IRKs (fig. 3B). A normal distribution does not indicate a positive or negative relationship to the explanatory variable, which is why we did not find a correlation in the overall occupancy model statistics.

Individual sites cannot be identified by the figures alone (figs. 1-3), so the values for each point (in other words, site) in all figures are reported in table 4. To demonstrate, S001-S003 and S009 were the only non-canal waterbodies sampled, and this was reflected in the lower probability of detecting eDNA at a site with $\psi$ values ranging from 0.28 to 0.47 , with S003 having 1.00 probability of detection. The only difference in site variables among the four non-canal sites was that S003 and S009 had structures present and S009 had a previous sighting of pythons. Yet of these four non-canal sites, S001 was the only non-canal waterbody site with a positive detection of pythons in water collected as part of this study. 

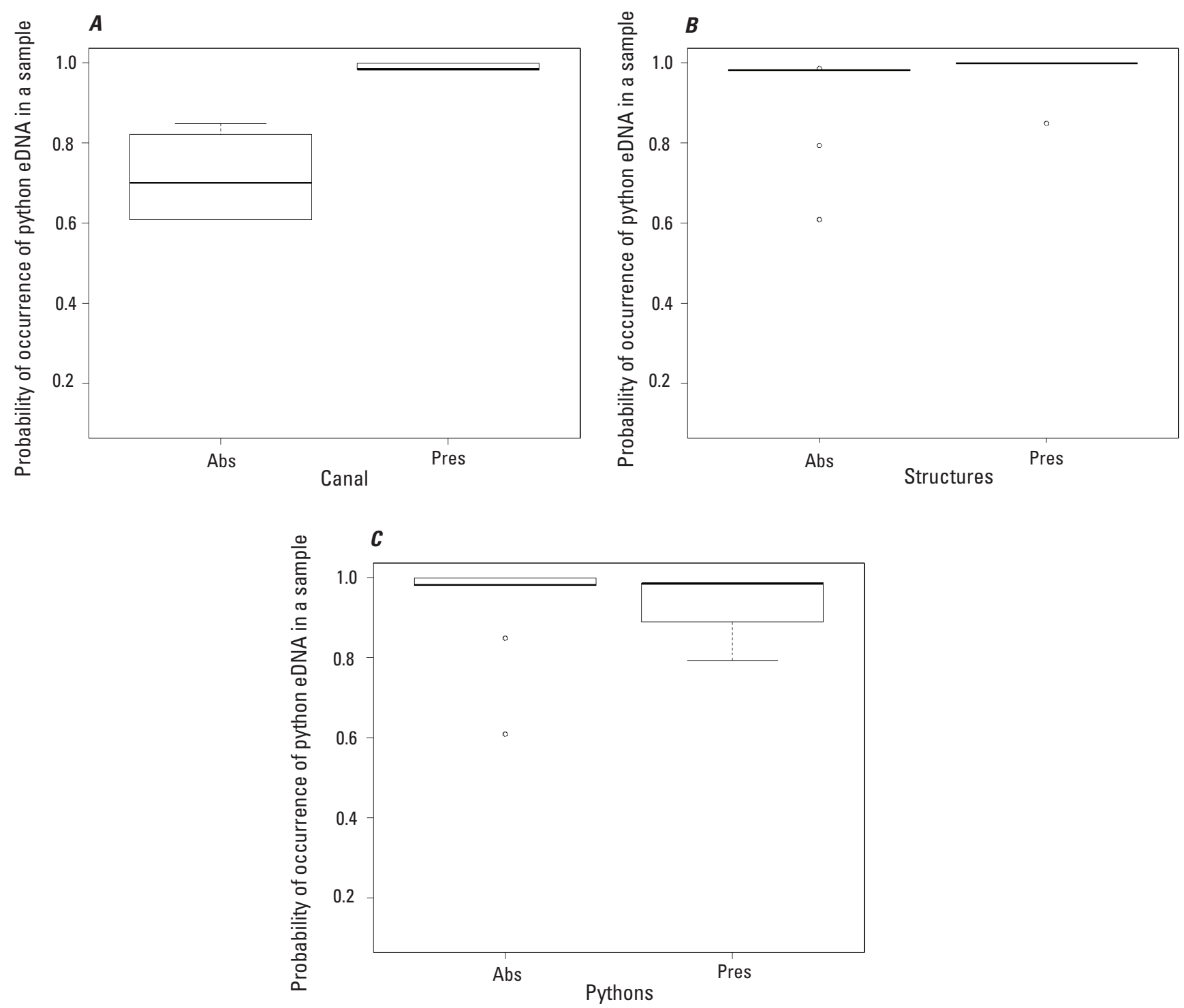

Figure 1. Results from Bayesian occupancy modeling assessing covariates that influence python eDNA occurrence at a sampling site: $A$, canal (Pres) or other waterbody (Abs); $B$, the presence (Pres) or absence (Abs) of structures (culverts, pumps, etc.); and $C$, python sightings (Pres) or no sightings (Abs) in the area of the sampling site. The box indicates the 95th percentile of the data, with the thick bar in the middle indicating the median. Dotted lines at the bottom or top of the plot indicate the minimum and maximum values, respectively. The open dots represent outliers. All covariates were measured as presence (Pres) and absence (Abs) binomial factors.

\section{Interpretation of Models and eDNA Concentrations Relating to Inhibitors}

Interpretations of the occupancy estimates for sampling sites should be made with caution, and both models could benefit from more sampling. Based on the levels of inhibition detected in these water samples, the results reflect a minimum of eDNA concentration found in the environment and should not be taken as what is realistically present. These models assume that abiotic factors and laboratory inhibition assessments were done in a standardized manner, collected for each site, and applied to each sample from those sites. The consistent numbers across mean, median, and 95-percent Confidence Intervals (CI) in the dataset can indicate imbalances in sample sizes. More sampling sites with varying habitat characteristics would improve models, statistical assessment of significance, and the resultant data interpretations. Additionally, the final number of IRKs variable is likely related to the intensity of inhibition, but after about three IRK columns, we ran an initial ddPCR; in some cases, fewer copies of eDNA were observed, even as inhibitors were often 

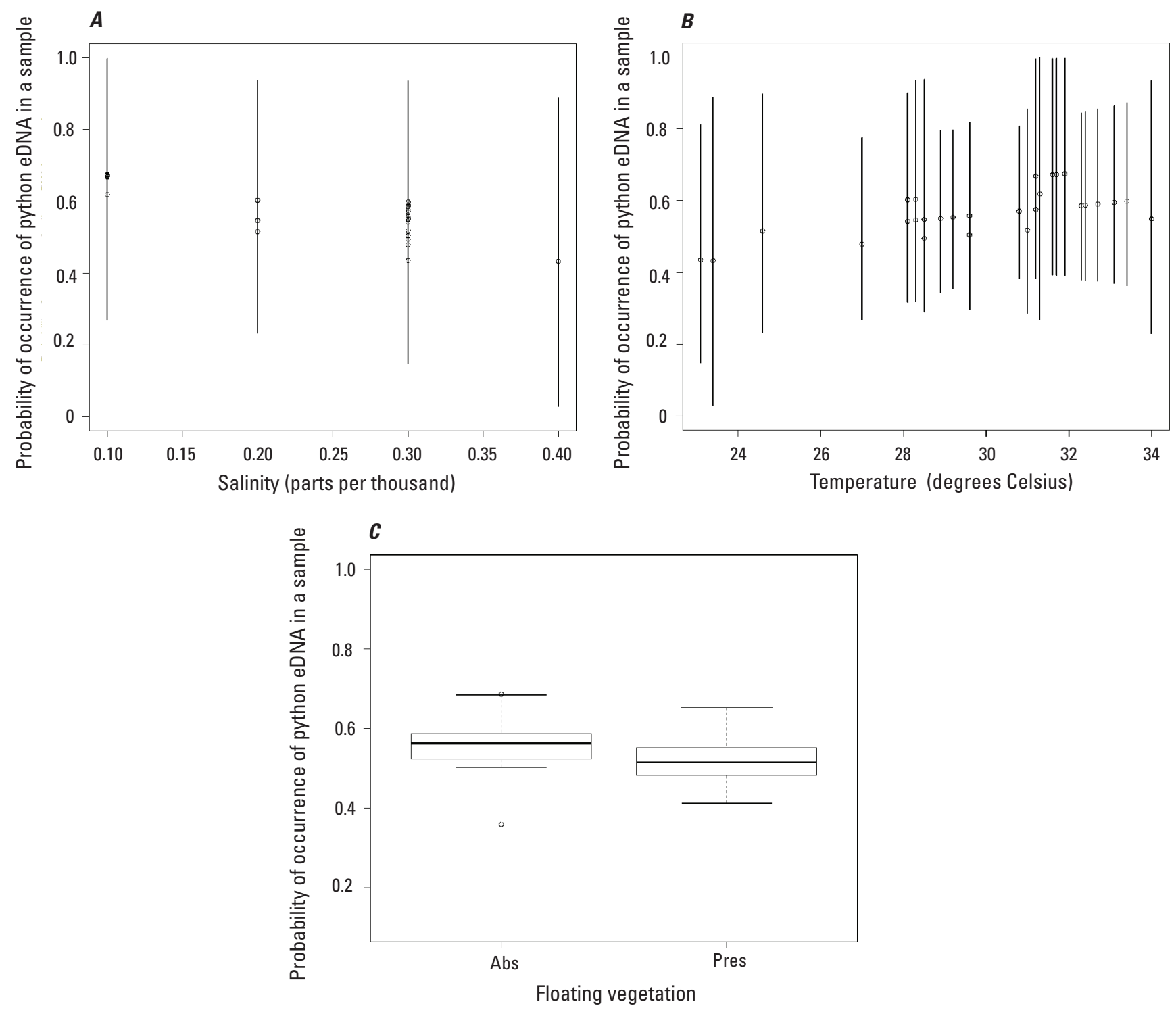

Figure 2. Results from Bayesian occupancy modeling assessing covariates that influence conditional probability of occurrence of python eDNA in an individual sample given that a python is present at a site: $A$, salinity; $B$, water temperature; and $C$, presence (Pres) or absence (Abs) of floating vegetation. Plots $A$ and $B$ have open circles representing medians and lines indicating 95-percent confidence intervals from the Bayesian Markov chain Monte Carlo iterations. The boxplots in $C$ indicate the 95th percentile of the data, with the thick bar in the middle indicating the median. Dotted lines at the bottom or top of the plot indicate the minimum and maximum values, respectively. The open dots represent outliers.

still present. There is a fine balance between running enough IRKs to remove inhibitors, but not running so many that remnant eDNA are removed. Traditionally, we run IRKs until samples lose their brown color (possibly caused by humic acid or tannins, known eDNA inhibitors) and become clear, but if samples do not become clear, the stopping point varies. Furthermore, we observed high levels of inhibition in clear samples. We targeted running the minimal number of IRKs necessary to obtain data for the study.

\section{PCR Inhibitors}

The water samples collected from the study sites were found to have a relatively high level of PCR inhibition, compared to other eDNA studies. Common PCR inhibitors are tannins from trees or humic acid in the soils that bind to the eDNA and inhibit the PCR amplifications used to copy and visualize the eDNA. Efforts have been made to develop an improved protocol to analyze eDNA from water containing PCR inhibitors (Hunter and others, 2019a); however, the samples from this study contained very high levels of PCR inhibitors, which need to be removed during the PCR isolations, 


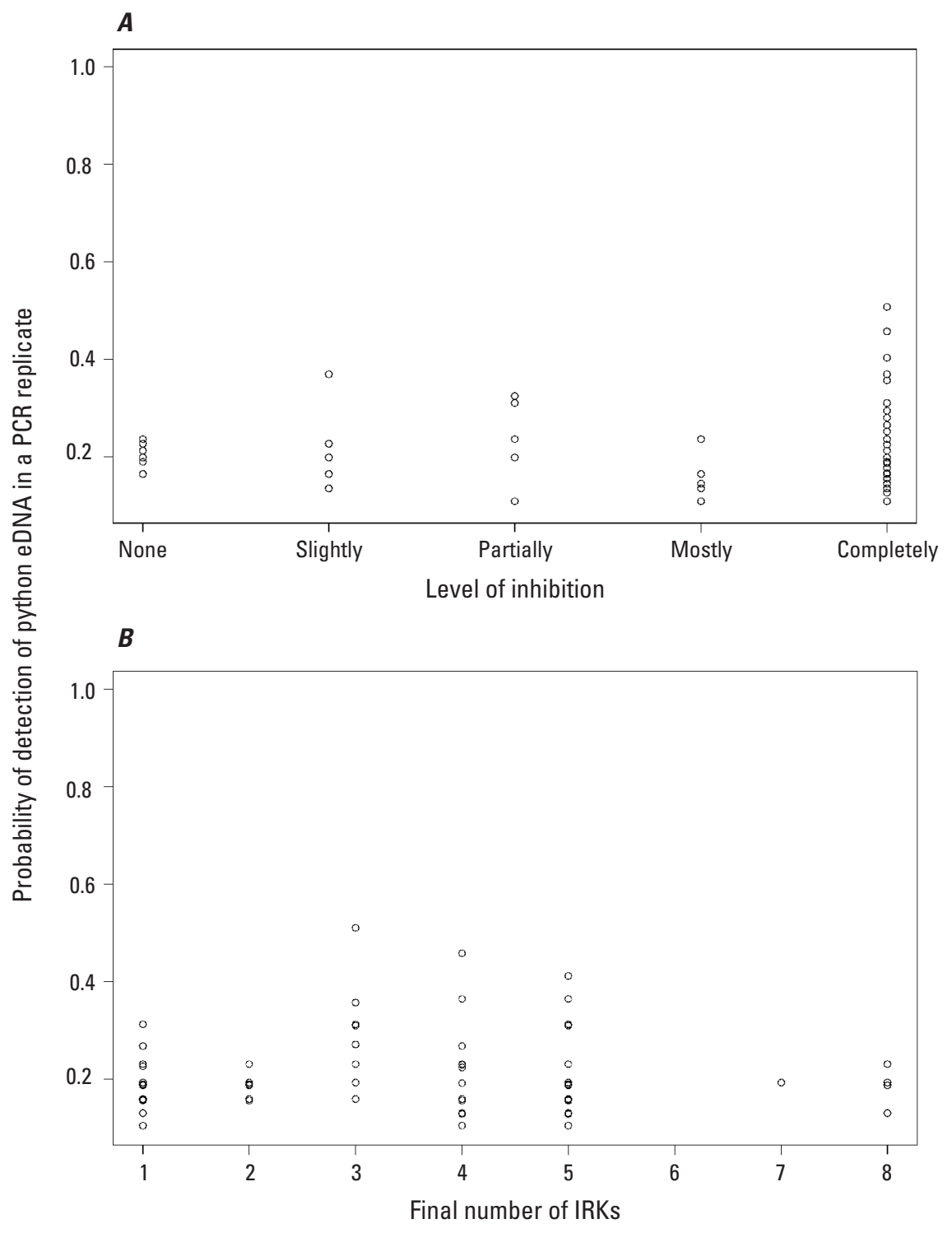

Figure 3. Results from Bayesian occupancy modeling assessing covariates that influence conditional probability of occurrence of python eDNA in a PCR replicate given that python eDNA is present in a sample: $A$, levels of inhibition; $B$, final number of Inhibitor Removal Kits (IRKs). The median probability of detection is indicated by open circles.

directly after filtration. After the high levels of inhibitors were identified, further attempts were made to continue to improve these inhibitor-removal methods; however, time and resources did not allow for this to take place. As a result, the copy number and concentrations of Burmese python eDNA detected by ddPCR may be less than what was actually present in a water sample, and the chances of false-negative detections (in other words, detecting zero python eDNA copies when there was in fact eDNA in the sample) were likely increased. The presence of inhibitors in these samples provide a caveat to the data analyzed and presented here, such that the occurrence of python eDNA may have been higher than what was detected in the current study. Inhibitors and eDNA have been found to be highly heterogenous and variable in the environment, a common challenge in eDNA studies (McKee and others, 2015; Pierson and others, 2016).

The low concentrations of target eDNA were likely primarily influenced by the inhibitors but also were influenced by the eDNA shedding rates of this semiaquatic reptile. Fish and amphibians are typical taxa targeted for eDNA assessment, and many protocols have been tested and developed for them because of their high eDNA shedding rates (Takahara and others, 2012; Sassoubre and others, 2016). Snakes, however, do not consistently shed skin cells, waste, or mucus, which are the common sources of eDNA for fish (Hunter and others, 2015). Snakes also feed intermittently, sometimes fasting for weeks on end, which greatly reduces the source of waste products.

Alternatively, the low concentrations could be indicative of fewer animals, low residency time of the animal in that area, or residual eDNA from another area that was carried through the system, although transport times can vary depending on system characteristics (Laramie and others, 2015; Orzechowski and others, 2019). Results from this study suggest very limited transport distances of eDNA in the Greater Everglades Ecosystem, likely due to low concentrations and degradation by environmental sources such as high UV levels, high temperatures, and low $\mathrm{pH}$. However, the specific flow rate for the canal or marsh and any eddies or mechanisms affecting transport would need to be individually assessed for each location to determine the rate of eDNA degradation. This low level of eDNA shed by pythons, combined with the harsh environmental conditions of the Everglades, indicates that the likelihood of eDNA being brought in from other systems through interconnected canals or predatory birds is low. Burmese python hatchlings average 22 inches and grow extremely rapidly, thus limiting the size of predatory animals that would consume them (Hart and others, 2012).

The eDNA detections represent a minimum of the eDNA present; however, the climate of South Florida and limited eDNA shed by constrictor snakes reduce the time span and distance that eDNA can travel downstream. Characterizing flow and transport of eDNA in various systems and for various 
Table 4. Bayesian occupancy model results reported for each site.

[Median probabilities of python environmental DNA occurrence over all iterations by sampling site $(\psi)$, individual sample $(\theta)$, and PCR replicate $(\rho)$ with 95-percent (\%) confidence intervals (CI) once covariates were considered. Parameters $\psi$ and $\theta$ were kept constant when computing $\rho$ values]

\begin{tabular}{|c|c|c|c|c|c|c|}
\hline Site & $\Psi$ & $95 \% \mathrm{Cl}$ & $\theta$ & $95 \% \mathrm{Cl}$ & $\rho$ & $95 \% \mathrm{Cl}$ \\
\hline S001 & 0.61 & $0.33-0.88$ & 0.60 & $0.38-0.90$ & 0.19 & $0.09-0.34$ \\
\hline S002 & 0.61 & $0.33-0.88$ & 0.43 & $0.03-0.89$ & 0.19 & $0.13-0.28$ \\
\hline S003 & 0.85 & $0.78-0.97$ & 0.57 & $0.38-0.81$ & 0.23 & $0.15-0.33$ \\
\hline S004 & 0.98 & $0.91-0.99$ & 0.59 & $0.38-0.84$ & 0.19 & $0.11-0.29$ \\
\hline S005 & 0.98 & $0.91-0.99$ & 0.60 & $0.36-0.87$ & 0.16 & $0.08-0.27$ \\
\hline S006 & 1.00 & $0.91-1.00$ & 0.59 & $0.37-0.86$ & 0.16 & $0.10-0.24$ \\
\hline S007 & 1.00 & $0.91-1.00$ & 0.59 & $0.37-0.86$ & 0.16 & $0.08-0.27$ \\
\hline S008 & 0.98 & $0.91-0.99$ & 0.59 & $0.38-0.85$ & 0.16 & $0.08-0.27$ \\
\hline S009 & 0.79 & $0.44-0.97$ & 0.55 & $0.32-0.94$ & 0.19 & $0.11-0.29$ \\
\hline S010 & 0.98 & $0.91-0.99$ & 0.54 & $0.32-0.80$ & 0.36 & $0.22-0.52$ \\
\hline S011 & 0.98 & $0.91-0.99$ & 0.55 & $0.34-0.80$ & 0.23 & $0.16-0.32$ \\
\hline S012 & 0.98 & $0.95-1.00$ & 0.60 & $0.38-0.90$ & 0.23 & $0.16-0.32$ \\
\hline S013 & 0.98 & $0.91-0.99$ & 0.52 & $0.23-0.90$ & 0.23 & $0.16-0.32$ \\
\hline S014 & 1.00 & $0.91-1.00$ & 0.49 & $0.29-0.80$ & 0.31 & $0.22-0.42$ \\
\hline S015 & 0.98 & $0.91-0.99$ & 0.58 & $0.38-0.82$ & 0.16 & $0.10-0.24$ \\
\hline S016 & 1.00 & $0.91-1.00$ & 0.52 & $0.29-0.85$ & 0.16 & $0.10-0.24$ \\
\hline S017 & 0.98 & $0.91-0.99$ & 0.50 & $0.30-0.82$ & 0.16 & $0.10-0.24$ \\
\hline S018 & 1.00 & $0.91-1.00$ & 0.55 & $0.23-0.94$ & 0.23 & $0.16-0.32$ \\
\hline S019 & 0.98 & $0.91-0.99$ & 0.55 & $0.32-0.94$ & 0.23 & $0.16-0.32$ \\
\hline S020 & 1.00 & $0.91-1.00$ & 0.56 & $0.36-0.79$ & 0.23 & $0.16-0.32$ \\
\hline S021 & 1.00 & $0.91-1.00$ & 0.55 & $0.35-0.80$ & 0.13 & $0.07-0.22$ \\
\hline S022 & 0.98 & $0.95-1.00$ & 0.44 & $0.15-0.81$ & 0.16 & $0.10-0.24$ \\
\hline S023 & 1.00 & $0.91-1.00$ & 0.48 & $0.27-0.78$ & 0.19 & $0.13-0.28$ \\
\hline S024 & 0.98 & $0.91-0.99$ & 0.67 & $0.39-1.00$ & 0.19 & $0.13-0.28$ \\
\hline S025 & 1.00 & $0.91-1.00$ & 0.62 & $0.27-1.00$ & 0.27 & $0.18-0.37$ \\
\hline S026 & 0.98 & $0.95-1.00$ & 0.67 & $0.39-1.00$ & 0.23 & $0.16-0.32$ \\
\hline S027 & 0.98 & $0.91-0.99$ & 0.67 & $0.39-1.00$ & 0.31 & $0.22-0.42$ \\
\hline S028 & 0.98 & $0.91-0.99$ & 0.67 & $0.39-1.00$ & 0.23 & $0.16-0.32$ \\
\hline
\end{tabular}

species is a large challenge faced by the eDNA community, and although numerous studies have been published, the variable nature of environments that might be targeted for eDNA surveys across the world make it difficult to standardize measurements of eDNA transport (Shogren and others, 2017; Jeunen and others, 2019; Sepulveda and others, 2019). The evaluation of site-specific flow and transport for each type of habitat in a study is critical. Further, these factors can be influenced by water levels (recent rain events), the season of sampling (affecting the environmental characteristics [for example temperature] and the shed rates of the target species), the location of sampling (shore or midstream; surface, subsurface, or at depth), and other factors that are still under investigation (Moyer and others, 2014, Klymus and others, 2015, Erickson and others, 2016).

\section{Recommendations for Future Studies}

The relationships among detection/nondetection and inhibition levels with abiotic factors were inconclusive. However, the sampling sites in the dataset are skewed towards canal systems ( 24 of the 28 sites) and most sites ( 25 out of 28) had detection of python eDNA under the liberal criterion. Although most canal sites had detections of python eDNA, for future sampling efforts in the Greater Everglades Ecosystem, we recommend a variety of sampling sites, such as remote ponds, lakes, or reservoirs. The lack of water flow in these lentic areas and inconsistent water levels provide opportunity for a more consistent sampling of time and place for the target animal but can also concentrate inhibitors (McKee and others, 2015). For example, site S002 is a small and remote pond, and 
samples were still completely inhibited. Ongoing efforts to improve PCR inhibition removal could result in improved data analyses. More extensive sampling of this and other study sites could assist in finding heavily trafficked areas or areas where pythons seem established. Repeated sampling, specifically for areas of interest, would help to allow for better interpretation of the results. If the python eDNA is detected from repeated sampling efforts, that would suggest the original detection is not something that is random/unlikely (such as secondhand eDNA from bird feces; Wilcox and others [2016]). Sampling the same sites over multiple years could also help to ascertain changes in occurrence and detection rates, which could help to determine changes in immigration into the area. Sampling the same sites during different seasons throughout the year may also allow for detection of the highest levels of eDNA and may improve detection estimates, due to more suitable environmental conditions (cooler water and reduced UV radiation) and snake behavior, such as mating during the fall and winter.

\section{References Cited}

Beaver, C.E., Meigs-Friend, G., and Hunter, M.E., 2021, Droplet digital PCR data for environmental DNA surveys of Burmese pythons in the Greater Everglades Ecosystem: U.S. Geological Survey data release, https://doi.org/ 10.5066/P9HVM4VQ.

Collins, R.A., Wangensteen, O.S., O'Gorman, E.J., Mariani, S., Sims, D.W., and Genner, M.J., 2018, Persistence of environmental DNA in marine systems: Communications Biology, v. 1, no. 1, p. 185. [Also available at https://doi.org/10.1038/s42003-018-0192-6.]

Darling, J.A., and Mahon, A.R., 2011, From molecules to management-Adopting DNA-based methods for monitoring biological invasions in aquatic environments: Environmental Research, v. 111, no. 7, p. 978-988. [Also available at https://doi.org/10.1016/j.envres.2011.02.001.]

Dejean, T., Valentini, A., Duparc, A., Pellier-Cuit, S., Pompanon, F., Taberlet, P., and Miaud, C., 2011, Persistence of environmental DNA in Freshwater Ecosystems: PLoS ONE, v. 6, no. 8, article e23398. [Also available at https://doi.org/10.1371/journal.pone.0023398.]

Díaz-Ferguson, E., 2014, Development of molecular markers for eDNA detection of the invasive African jewelfish (Hemichromis letourneuxi) - A new tool for monitoring aquatic invasive species in National Wildlife Refuges: Management of Biological Invasions: International Journal of Applied Research on Biological Invasions, v. 5, no. 2, p. 121-131. [Also available at https://doi.org/10.3391/ mbi.2014.5.2.05.]
Doi, H., Uchii, K., Takahara, T., Matsuhashi, S., Yamanaka, H., and Minamoto, T., 2015, Use of droplet digital PCR for estimation of fish abundance and biomass in environmental DNA surveys: PLoS ONE, v. 10, no. 3, article e0122763. [Also available at https://doi.org/10.1371/ journal.pone.0122763.]

Dorazio, R.M., and Erickson, R.A., 2018, EDNAOCCUPANCY - An R package for multiscale occupancy modelling of environmental DNA data: Molecular Ecology Resources, v. 18, no. 2, p. 368-380. [Also available at https://doi.org/10.1111/1755-0998.12735.]

Dorazio, R.M., and Hunter, M.E., 2015, Statistical models for the analysis and design of digital polymerase chain reaction (dPCR) experiments: Analytical Chemistry, v. 87, no. 21, p. 10886-10893. [Also available at https://doi.org/10.1021/ acs.analchem.5b02429.]

Dove, C.J., Snow, R.W., Rochford, M.R., and Mazzotti, F.J., 2011, Birds consumed by the invasive Burmese python (Python molurus bivittatus) in Everglades National Park, Florida, USA: The Wilson Journal of Ornithology, v. 123, no. 1, p. 126-131. [Also available at https://doi.org/10.1676/ 10-092.1.]

Erickson, R.A., Rees, C.B., Coulter, A.A., Merkes, C.M., McCalla, S.G., Touzinsky, K.F., Walleser, L., Goforth, R.R., and Amberg, J.J., 2016, Detecting the movement and spawning activity of bigheaded carps with environmental DNA: Molecular Ecology Resources, v. 16, no. 4, p. 957-965. [Also available at https://doi.org/10.1111/17550998.12533.]

Esri, 2018, ArcGIS Desktop—Release 10.6.1: Redlands, Calif., Environmental Systems Research Institute.

Furlan, E.M., Gleeson, D., Hardy, C.M., and Duncan, R.P., 2016, A framework for estimating the sensitivity of eDNA surveys: Molecular Ecology Resources, v. 16, no. 3, p. 641-654. [Also available at https://doi.org/10.1111/17550998.12483.]

Goldberg, C.S., Pilliod, D.S., Arkle, R.S., and Waits, L.P., 2011, Molecular detection of vertebrates in stream water-A demonstration using Rocky Mountain tailed frogs and Idaho giant salamanders: PLoS ONE, v. 6, no. 7, article e22746. [Also available at https://doi.org/10.1371/ journal.pone.0022746.] 
Goldberg, C.S., Turner, C.R., Deiner, K., Klymus, K.E., Thomsen, P.F., Murphy, M.A., Spear, S.F., McKee, A., Oyler-McCance, S.J., Cornman, R.S., Laramie, M.B., Mahon, A.R., Lance, R.F., Pilliod, D.S., Strickler, K.M., Waits, L.P., Fremier, A.K., Takahara, T., Herder, J.E., and Taberlet, P., 2016, Critical considerations for the application of environmental DNA methods to detect aquatic species: Methods in Ecology and Evolution, v. 7, no. 11, p. 1299-1307. [Also available at https://doi.org/10.1111/ 2041-210X.12595.]

Greene, D.U., Potts, J.M., Duquesnel, J.G., and Snow, R.W., 2007, Geographic distribution-Python molurus bivittatus (Burmese python): Herpetological Review, v. 38, p. 355.

Hart, K.M., Schofield, P.J., and Gregoire, D.R., 2012, Experimentally derived salinity tolerance of hatchling Burmese pythons (Python molurus bivittatus) from the Everglades, Florida (USA): Journal of Experimental Marine Biology and Ecology, v. 413, p. 56-59. [Also available at https://doi.org/10.1016/j.jembe.2011.11.021.]

Hayden, R.T., Gu, Z., Ingersoll, J., Abdul-Ali, D., Shi, L., Pounds, S., and Caliendo, A.M., 2013, Comparison of droplet digital PCR to real-time PCR for quantitative detection of cytomegalovirus: Journal of Clinical Microbiology, v. 51, no. 2, p. 540-546. [Also available at https://doi.org/10.1128/ JCM.02620-12.]

Huggett, J.F., Foy, C.A., Benes, V., Emslie, K., Garson, J.A., Haynes, R., Hellemans, J., Kubista, M., Mueller, R.D., Nolan, T., Pfaffl, M.W., Shipley, G.L., Vandesompele, J., Wittwer, C.T., and Bustin, S.A., 2013, The digital MIQE guidelines-Minimum information for publication of quantitative digital PCR experiments: Clinical Chemistry, v. 59, no. 6, p. 892-902. [Also available at https://doi.org/ 10.1373/clinchem.2013.206375.]

Hunter, M.E., Dorazio, R.M., Butterfield, J.S., MeigsFriend, G., Nico, L.G., and Ferrante, J.A., 2017, Detection limits of quantitative and digital PCR assays and their influence in presence-absence surveys of environmental DNA: Molecular Ecology Resources, v. 17, no. 2, p. 221-229. [Also available at https://doi.org/10.1111/17550998.12619.]

Hunter, M.E., Ferrante, J.A., Meigs-Friend, G., and Ulmer, A., 2019a, Improving eDNA yield and inhibitor reduction through increased water volumes and multi-filter isolation techniques: Scientific Reports, v. 9, no. 1, article 5259. [Also available at https://doi.org/10.1038/s41598-01940977-w.]
Hunter, M.E., Meigs-Friend, G., Ferrante, J.A., Smith, B.J., and Hart, K.M., 2019b, Efficacy of eDNA as an early detection indicator for Burmese pythons in the ARM Loxahatchee National Wildlife Refuge in the Greater Everglades Ecosystem: Ecological Indicators, v. 102, p. 617-622. [Also available at https://doi.org/10.1016/ j.ecolind.2019.02.058.]

Hunter, M.E., Oyler-McCance, S.J., Dorazio, R.M., Fike, J.A., Smith, B.J., Hunter, C.T., Reed, R.N., and Hart, K.M., 2015, Environmental DNA (eDNA) sampling improves occurrence and detection estimates of invasive burmese pythons: PLoS ONE, v. 10, no. 4, article e0121655. [Also available at https://doi.org/10.1371/journal.pone.0121655.]

Jerde, C.L., Mahon, A.R., Chadderton, W.L., and Lodge, D.M., 2011, "Sight-unseen" detection of rare aquatic species using environmental DNA: Conservation Letters, v. 4, no. 2, p. 150-157. [Also available at https://doi.org/10.1111/ j.1755-263X.2010.00158.x.]

Jeunen, G.J., Knapp, M., Spencer, H.G., Lamare, M.D., Taylor, H.R., Stat, M., Bunce, M., and Gemmell, N.J., 2019, Environmental DNA (eDNA) metabarcoding reveals strong discrimination among diverse marine habitats connected by water movement: Molecular Ecology Resources, v. 19, no. 2, p. 426-438. [Also available at https://doi.org/10.1111/ 1755-0998.12982.]

Klymus, K.E., Richter, C.A., Chapman, D.C., and Paukert, C., 2015, Quantification of eDNA shedding rates from invasive bighead carp Hypophthalmichthys nobilis and silver carp Hypophthalmichthys molitrix: Biological Conservation, v. 183, p. 77-84. [Also available at https://doi.org/10.1016/ j.biocon.2014.11.020.]

Kolar, C., Courtenay, W.J., Nico, L., and Hubert, W., 2010, Managing undesired and invading fishes: Bethesda, Md., American Fisheries Society.

La Grange, A., le Roux, N., and Gardner-Lubbe, S., 2009, BiplotGUI-Interactive biplots in R: Journal of Statistical Software, v. 30, no. 12. [Also available at https://doi.org/ 10.18637/jss.v030.i12.]

Laramie, M.B., Pilliod, D.S., and Goldberg, C.S., 2015, Characterizing the distribution of an endangered salmonid using environmental DNA analysis: Biological Conservation, v. 183, p. 29-37. [Also available at https://doi.org/10.1016/j.biocon.2014.11.025.]

Lodge, D.M., Williams, S., MacIsaac, H.J., Hayes, K.R., Leung, B., Reichard, S., Mack, R.N., Moyle, P.B., Smith, M., Andow, D.A., Carlton, J.T., and McMichael, A., 2006, Biological invasions - Recommendations for U.S. policy and management: Ecological Applications, v. 16, no. 6, p. 2035-2054. [Also available at https://doi.org/10.1890/ 1051-0761(2006)016[2035:BIRFUP]2.0.CO;2.] 
Mahon, A.R., Jerde, C.L., Galaska, M., Bergner, J.L., Chadderton, W.L., Lodge, D.M., Hunter, M.E., and Nico, L.G., 2013, Validation of eDNA surveillance sensitivity for detection of Asian carps in controlled and field experiments: PLoS ONE, v. 8, no. 3, article e58316. [Also available at https://doi.org/10.1371/journal.pone.0058316.]

McKee, A.M., Calhoun, D.L., Barichivich, W.J., Spear, S.F., Goldberg, C.S., and Glenn, T.C., 2015, Assessment of environmental DNA for detecting presence of imperiled aquatic amphibian species in isolated wetlands: Journal of Fish and Wildlife Management, v. 6, no. 2, p. 498-510. [Also available at https://doi.org/10.3996/042014-JFWM-034.]

Mosher, B.A., Huyvaert, K.P., and Bailey, L.L., 2018, Beyond the swab-Ecosystem sampling to understand the persistence of an amphibian pathogen: Oecologia, v. 188, no. 1, p. 319-330. [Also available at https://doi.org/10.1007/ s00442-018-4167-6.]

Moyer, G.R., Diaz-Ferguson, E., Hill, J.E., and Shea, C., 2014, Assessing environmental DNA detection in controlled lentic systems: PLoS ONE, v. 9, no. 7, article e103767. [Also available at https://doi.org/10.1371/journal.pone.0103767.]

Orzechowski, S.C.M., Frederick, P.C., Dorazio, R.M., and Hunter, M.E., 2019, Environmental DNA sampling reveals high occupancy rates of invasive Burmese pythons at wading bird breeding aggregations in the central Everglades: PLoS ONE, v. 14, no. 4, article e0213943. [Also available at https://doi.org/10.1371/journal.pone.0213943.]

Pierson, T.W., McKee, A.M., Spear, S.F., Maerz, J.C., Camp, C.D., and Glenn, T.C., 2016, Detection of an enigmatic plethodontid salamander using environmental DNA: Copeia, v. 104, no. 1, p. 78-82. [Also available at https://doi.org/10.1643/CH-14-202.]

R Core Team, 2019, R-A language and environment for statistical computing: R Foundation for Statistical Computing.

Reed, R.N., Hart, K.M., Rodda, G.H., Mazzotti, F.J., Snow, R.W., Cherkiss, M., Rozar, R., and Goetz, S., 2011, A field test of attractant traps for invasive Burmese pythons (Python molurus bivittatus) in southern Florida: Wildlife Research, v. 38, no. 2, p. 114-121. [Also available at https://doi.org/10.1071/WR10202.]

Renshaw, M.A., Olds, B.P., Jerde, C.L., McVeigh, M.M., and Lodge, D.M., 2015, The room temperature preservation of filtered environmental DNA samples and assimilation into a phenol-chloroform-isoamyl alcohol DNA extraction: Molecular Ecology Resources, v. 15, no. 1, p. 168-176. [Also available at https://doi.org/10.1111/17550998.12281.]
Sassoubre, L.M., Yamahara, K.M., Gardner, L.D., Block, B.A., and Boehm, A.B., 2016, Quantification of environmental DNA (eDNA) shedding and decay rates for three marine fish: Environmental Science \& Technology, v. 50, no. 19 , p. 10456-10464. [Also available at https://doi.org/ 10.1021/acs.est.6b03114.]

Sepulveda, A.J., Amberg, J.J., and Hanson, E., 2019, Using environmental DNA to extend the window of early detection for dreissenid mussels: Management of Biological Invasions: International Journal of Applied Research on Biological Invasions, v. 10, no. 2, p. 342-358. [Also available at https://doi.org/10.3391/mbi.2019.10.2.09.]

Shogren, A.J., Tank, J.L., Andruszkiewicz, E., Olds, B., Mahon, A.R., Jerde, C.L., and Bolster, D., 2017, Controls on eDNA movement in streams - Transport, retention, and resuspension: Scientific Reports, v. 7, article 5065. [Also available at https://doi.org/10.1038/s41598-017-05223-1.]

Smith, B.J., Cherkiss, M.S., Hart, K.M., Rochford, M.R., Selby, T.H., Snow, R.W., and Mazzotti, F.J., 2016, Betrayal-Radio-tagged Burmese pythons reveal locations of conspecifics in Everglades National Park: Biological Invasions, v. 18, no. 11, p. 3239-3250. [Also available at https://doi.org/10.1007/s10530-016-1211-5.]

Snow, R.W., Brien, M.L., Cherkiss, M.S., Wilkins, L., and Mazzotti, F.J., 2007, Dietary habits of the Burmese python, Python molurus bivittatus, in Everglades National Park, Florida: Herpetological Bulletin, no. 101, p. 5-7. [Also available at https://www.semanticscholar.org/paper/Dietaryhabits-of-the-Burmese-python\%2C-Python-in-Snow-Brien/ 86abadc2abaa11d9af9f75a866e147cded3f4de9.]

Takahara, T., Minamoto, T., Yamanaka, H., Doi, H., and Kawabata, Z.i., 2012, Estimation of fish biomass using environmental DNA: PLoS ONE, v. 7, no. 4, article e35868. [Also available at https://doi.org/10.1371/ journal.pone.0035868.]

Thomsen, P.F., Kielgast, J., Iversen, L.L., Moller, P.R., Rasmussen, M., and Willerslev, E., 2012a, Detection of a diverse marine fish fauna using environmental DNA from seawater samples: PLoS ONE, v. 7, no. 8, article e41732. [Also available at https://doi.org/10.1371/ journal.pone.0041732.]

Thomsen, P.F., Kielgast, J.O.S., Iversen, L.L., Wiuf, C., Rasmussen, M., Gilbert, M.T.P., Orlando, L., and Willerslev, E., 2012b, Monitoring endangered freshwater biodiversity using environmental DNA: Molecular Ecology, v. 21, no. 11, p. 2565-2573. [Also available at https://doi.org/ 10.1111/j.1365-294X.2011.05418.x.] 
Whale, A.S., Huggett, J.F., Cowen, S., Speirs, V., Shaw, J., Ellison, S., Foy, C.A., and Scott, D.J., 2012, Comparison of microfluidic digital PCR and conventional quantitative PCR for measuring copy number variation: Nucleic Acids Research, v. 40, no. 11, p. e82. [Also available at https://doi.org/10.1093/nar/gks203.]
Wilcox, T.M., McKelvey, K.S., Young, M.K., Sepulveda, A.J., Shepard, B.B., Jane, S.F., Whiteley, A.R., Lowe, W.H., and Schwartz, M.K., 2016, Understanding environmental DNA detection probabilities-A case study using a stream-dwelling char Salvelinus fontinalis: Biological Conservation, v. 194, p. 209-216. [Also available at https://doi.org/10.1016/j.biocon.2015.12.023.] 


\section{Appendix 1. Definitions and Explanations for Frequently Used Terminology}

"PCR Replicate" refers to polymerase chain reactions (PCR) performed to amplify python eDNA for each sample. Five replicates for each sample were run in a droplet digital PCR each time.

"Sample" refers to a single water bottle collected at a sampling site. Five water bottles were collected at each site and were considered replicates of each other. Each sample was characterized by a letter $(\mathrm{A}-\mathrm{E})$ at the end of the sample name (for example, S001A).
"Site" refers to the collective data from the five samples in reference to a single sampling station

"Template" refers to the material that was processed and tested for potential eDNA molecules (for example, 1 liter of water collected). 

For more information about this publication, contact

Director, Wetland and Aquatic Research Center

U.S. Geological Survey

700 Cajundome Blvd.

Lafayette, LA 70506-3152

For additional information, visit https://www.usgs.gov/centers/ wetland-and-aquatic-research-center-warc

Publishing support provided by Lafayette Publishing Service Center 


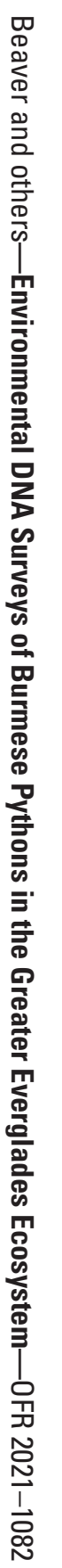

